\title{
KEUNIKAN DAKWAH HALAQAH TARBIYAH: STUDI PADA HALAQAH TARBIYAH PKS
}

\author{
Cucu
}

\begin{abstract}
Abstrak
Dinatara faktor kesuksesan dakwah adalah pemilihan metode dakwah yang tepat yang disesuaikan dengan kondisi mad'unya. Kesuksesan dakwah terbuka Nabi Saw disebabkan adanya tenaga da'i yakni para shahabat yang memiliki ketangguhan dalam berbagai hal. Pembentukan tenaga da'i pada masa Nabi ini , dilakukan melalui metode halaqah yang dilakukan Nabi secara intensif di rumah Al-Arqam, dan juga halaqah tarbiyah di periode Madinah. Melalui metode halaqah tarbiyah, bukan sekedar pertemuan untuk menyampaikan materi dakwah, namun pada halaqah tarbiyah terdapat kedekatan yang dibangun antara da'i dengan mad'unya, dan keadaan ini dapat menjadi kesempatan untuk memperkuat kader dakwah.
\end{abstract}

Kata Kunci: Halaqah Tarbiyah, Sebuah Metode Dakwah

\section{A. Pendahuluan}

Menurut Jalaluddin Rahmat, ada tiga hal penting sehubungan dengan proses perubahan masyarakat, yaitu pertama bagaimana ide atau gagasan mempengaruhi perubahan social, kedua bagaimana tokoh-tokoh besar dalam sejarah mempengaruhi perubahan besar di tengah-tengah masyarakat, dan ketiga sejauh mana peranan gerakan - gerakan social dan revolusi menimbulkan perubahan struktur social dan normanorma social. ${ }^{1}$ Gerakan social dalam

\footnotetext{
${ }^{1}$ Jalaluddin Rahmat, Rekayasa Sosial: Reformasi atau Revolusi, (Bandung: PT Remaja Rosda Karya, 1999), hlm. 103
}

Islam secara umum dikenal dengan sebutan "dakwah" yang secara bahasa memiliki beberapa arti, yaitu memanggil, mengundang, minta tolong, meminta, memohon, menamakan, menyuruh datang, mendorong, menyebabkan, mendatangkan, mendo'akan, menangisi dan meratapi. ${ }^{2}$

Memperhatikan perjalanan gerakan dakwah yang sudah diperankan Nabi Muhammad saw., dapat dikatakan bahwa secara hakikat dakwah memiliki fungsi sebagai (1) gerakan perubahan

\footnotetext{
${ }^{2}$ Ahmad warson Munawwir, Al-Munawwir Kamus ArabIndonesia, (Surabaya: Pustaka Progresif, 1997), hIm. 407
} 
kepribadian seseorang dan (2) masyarakat secara kultural. Ditinjau dari aktivitasnya, dakwah memiliki tujuan pada tiga hal, yaitu: (1) menegakkan Islam di muka bumi; (2) amr ma'ruf, yaitu upaya mendorong dan menggerakan manusia agar mau menerima dan menerapkan ajaran Islam dalam kehidupan sehari-hari; (3) Nahi munkar, yakni mendorong dan menggerakan manusia untuk menolak dan meninggalkan hal-hal yang munkar ${ }^{3}$

Pada pelaksanaanya, dakwah dilakukan dengan berbagai bentuk kegiatan serta dengan metode yang beragam disesuaikan dengan kondisi mad'unya. Sebagaimana dalam catatan perjalanan dakwah $\mathrm{Nabi}$, terdapat dua metode dakwah yang diterapkan Nabi selama perjuangan dakwahnya, yaitu metode sembunyi-sembunyi dan terbuka. Begitu juga dalam perjalanan dakwah terbuka, ketika pertama kali Rasulullah Saw berhijrah dan mendirikan masjid AlTaqwa di Quba, menurut Samsul Nisar, bahwa pendidikan Islam yang diterapkan di masjid tersebut dinilai sangat unik, karena Nabi menggunakan system halaqah (lingkaran). ${ }^{4}$

Dengan berbagai jenis metode, gerakan dakwah nampaknya terus

\footnotetext{
${ }^{3}$ Munir, M. dan Wahyu Ilahi. 2009. Manajemen Dakwah. Jakarta: Prenada MediaGroup. hlm. 90-91

${ }^{4}$ Samsul Nisar, Sejarah Pendidikan Islam (menelusuri jejak Sejarah Pendidikan Era Rasulullah Sampai indonesia), jakarta; Kencana, 2007, HIm. 9-10
}

bergema termasuk di kota Pontianak Kalimantan Barat. Salah satu bentuk dakwah yang semakin tumbuh di kalangan masyarakat adalah kegiatan "majelis taklim". Sekalipun bersifat non formal, namun kehadiran majelis taklim di tengah masyarakat dapat dikatakan cukup berperan dalam membangun karakter bangsa, khususnya dalam membangun akhlak ibu-ibu sebagai guru utama di dalam rumah tangga. Untuk dapat mengoptimalkan peran majlis taklim tersebut, peran dan perhatian dari berbagai pihak khususnya para pegiat dakwah sangat dibutuhkan.

Salah satu faktor keberhasilan dakwah termasuk di majlis taklim, yakni penerapan metode yang tepat dan dibutuhkan oleh anggotanya. Jika memperhatikan perjalanan dakwah Nabi Muhammad saw, metode halaqah tarbiyah, merupakan metode dakwah yang sudah diterapkan Nabi dan dapat dikatakan efektif jika diterapkan pada kegiatan majlis taklim saat ini. Maka dari itu dalam tulisan ini penulis ingin mengupas tentang "Metode dakwah halaqah tarbiyah Nabi" baik secara teoritis maupun hasil penelitian di lapangan.

\section{B. Pengertian Halaqah Tarbiyah}

Secara bahasa Halaqah berasal dari kata "halaqa- yahluqu- halqatan" 
yang berarti lingkaran ${ }^{5}$. Sedangkan menurut istilah, halaqah merupakan sarana utama tarbiyah sebagai media untuk merealisasikan kurikulum tarbiyah. Selain itu halaqah juga dapat dikatakan sebagai satu proses kegiatan tarbiyah dalam dinamika kelompok dengan jumlah maksimal anggota12 orang. ${ }^{6}$ Halaqah bisa didefinisikan sebagai sebuah wahana tarbiyah (pembinaan), berupa kelompok kecil yang terdiri dari murabbi (pembina) dan sejumlah mutarabbi (binaan), dengan manhaj (kurikulum) yang jelas, dan diselenggarakan melalui berbagai macam sarana (perangkat) tarbiyah.

Dengan demikian, elemen-elemen halaqah adalah (1) murabbi, mutarabbi, (3) manhaj tarbiyah, dan (4) sarana (perangkat) tarbiyah. Dalam sebuah halaqah, murabbi dan mutarabbi bekerjasama untuk melaksanakan manhaj yang ada melalui sarana-sarana (perangkat-perangkat) yang sesuai.

Jika merujuk kepada teori ilmu dakwah, dakwah dalam bentuk halaqah dapat disamakan dengan bentuk dakwah "fiah. Menurut Enjang, dakwah fi'ah merupakan dakwah yang dilakukan seorang da'i terhadap kelompok kecil

\footnotetext{
5 Ahmad Warson Munawir, Kamus Al-Munawir ArabIndonesia, (Surabaya; Pustaka Progresif, 2002), hlm. 290.

6 Abdullah Qadiri, Adab halaqah, (Bandung: PT. AlMa'arif. 1993). HIm 32
}

dalam suasana tatap muka dan biasanya dilakukan dialog, sehingga respon mad'u dapat diketahui secara cepat. Ciri lain dari dakwah fi'ah adalah kelompok mad'u berupa kelompok kecil dan jenis kelompok mad'u disesuaikan dengan jenis kegiatan yang diselenggarakan, sehingga media, metode dan tujuan dakwah berdasarkan pertimbangan bentuk kegiatan. ${ }^{7}$ Fakhruddin Arroji dalam Miftahul Ghaib dalam Syukriadi Sambas menambahkan bahwa secara kuantitas dari dakwah fi'ah batas maksimal adalah 20 orang dan dikenal dengan fi'ah qalilah. Jika lebih dari batas tersebut, maka termasuk fi'ah katsirah dan itu menjadi kajian wilayah tabligh.

\section{Halaqah Tarbiyah pada Masa Nabi Saw}

Sudah sejak dini Rasulullah melakukan dakwah melalui pendekatan tarbiyah. Ketika di Makkah, seiring sampainya Islam di kalangan sahabat pendekatan tarbiyyah ini sudah berjalan sekalipun belum terorganisir, mengingat situasi Kota Makkah yang belum memungkinkan berkembangnya pendidikan. Diantara tempat yang digunakan adalah rumah sahabat Arqom bin Abi Arqom yang menjadi tempat pertama penyampaian dakwah secara berkelompok. Di rumah pemuda yang

\footnotetext{
${ }^{7}$ Enjang AS , Dasar-dasar , hlm. 68
} 
berasal dari bani Makhzum inilah Nabi melakukan pembinaan dan pengkaderan secara intensif. ${ }^{8}$ Keunggulan kelompok pertama, disebabkan juga, pada tahap persiapan ini dakwah dilakukan dengan" pertemuan yang intensif". Pada pertemuan ini Nabi mengajar dan membina para Shahabat dengan penyampaian Al-Qur'an yang diterima langsung dari Jibril, melakukan ibadah bersama dan tukar pikiran yang selalu ada solusi terbaik yang diberikan nabi. Akan tetapi yang lebih penting dari pengkaderan ini adalah adanya "kedekatan diantara pimpinan dalam hal ini Nabi dengan para Shahabatnya". Sekalipun seorang Nabi dan Rasul sekaligus pemimpin Ummat, tapi Nabi tidak memposisikan sebagai pemimpin dalam status sosialnya. Sehingga tidak ada kekakuan diantara mereka. Selain itu Nabi sangat mencintai para Shahabat ini. Diantara bukti kecintaan nabi ketika Khalid bin Walid berselisih dengan Abdurrahman bin 'Auf, dan ada yang melaporkan kepada Rasulullah, maka beliau bersabda; "Wahai Khalid, jangan engkau usik para sahabatku. Demi Allah, andaikan kamu punya emas sebesar gunung Uhud kemudian kamu infakan di jalan Allah, hal itu belum bisa menyamai

\footnotetext{
${ }^{8}$ Harjani Hefni, dkk, Metode Dakwah, (Jakarta: Prenada Media 2003) hal. 22
}

salah seorang dari sahabatku atau istrinya". 9

Sesudah Nabi hijrah ke Madinah, dakwah dengan pendekatan tarbiyah lebih terorganisir dan berkembang. Diantara tempat yang digunakan adalah Al-Suffah yaitu sebuah ruangan yang berada pada bagian masjid di madinah yang juga berfungsi sebagai tempat penampungan para siswa yang tidak mampu. Ada juga yang dikenal dengan Dar-al-Qurra. Secara kebahasaan berarti rumah para pembaca Al-Qur'an. Nampaknya Dar al-Qurra lebih semacam madrasah al-Qur'an. Selain itu ada juga Kuttab, yang secara bahasa berarti tempat belajar. Kuttab ini merupakan tempat belajar anak-anak, yang banyak ditemukan di Madinah. Kemudian juga rumah para sahabat dan masjid-masjid di Madinah dijadikan sarana tarbiyah. ${ }^{10}$

Mengenai masjid, dari Madinah inilah masjid dijadikan pusat tarbiyah umat Islam. Saat itu masjid Nabawi menjadi pabrik pencetakan masyarakat yang berperadaban tinggi. Dikatakan Samsul Nisar bahwa tarbiyah yang dilakukan di masjid Nabi merupakan pendidikan yang unik, karena menggunakan sisten "halaqah" yang berarti lingkaran. Dalam halaqah ini

\footnotetext{
${ }^{9}$ HR. Muslim, no. 2540

10 Ali Mustafa Yaqub, Sejarah dakwah (Jakarta: Pustaka Firdaus, 1997) hal 130
} 
biasanya sang ustadz atau syeikh duduk didekat dinding, sementara jama'ahnya duduk di depannya secara melingkar dengan lutut yang bersentuhan. Nisar menjelaskan bahwa dalam halaqah, metode diskusi dan dialog selalu diterapkan. Selain itu penjelasan materi oleh guru atau syeikh dimana sebelumnya Syeikh mendiktekan materi terlebih dahul, dan ini dikenal dengan metode imla. Di akhir pertemuan syeikh melakukan evaluasi terhadap kemampuan pesertanya. ${ }^{11}$

Kegiatan tarbiyah yang dilakukan Nabi sejak dari rumah sahabat Arqam hingga penggunaan masjid, menunjukan kesungguhan Nabi dalam membangun generasi yang cerdas serta dalam membangun kekuatan Islam sehingga akhirnya Islam terbentang luas. Keberhasilan nabi dalam mentarbiyah umatnya tidak terlepas dari tujuan dan program tarbiyah yang diterapkanya saat itu.

\section{Halaqah Tarbiyah Partai Keadilan Sejahtera/PKS Pontianak Kota}

1. Sejarah singkat halaqah tarbiyah PKS

Kegiatan tarbiyah yang ada di lingkungan partai keadilan sejahtera

\footnotetext{
${ }^{11}$ Samsul Nisar, Sejarah Pendidikan Islam (Menelusuri Jejak Sejarah Pendidikan Era Rasulullah sampai Indonesia, (Jakarta: Kencana, 2007) hlm. 9-10
}

atau PKS, merupakan kegiatan keagamaan yang sudah lama dilakukan oleh para kader PKS sebelum partai keadilan terbentuk. Jika partai keadilan muncul pertama kalinya pada pemilu 1999, gerakan tarbiyah sudah ada di Indonesia sejak tahun 1980-an, seiring dengan masuknya pemikiran-pemikiran pembaharuan Islam dari Mesir. Di awal kemunculanya, sasaran tarbiyah difokuskan di sekolah-sekolah dan kampus. Hal ini sebagai sarana yang paling efektif untuk melakukan introspeksi dan penyadaran Islam terhadap generasi muda; menumbuhkan semangat berdakwah sambil belajar kesabaran menghadapi kediktatoran orde baru; mengajak ke jalan dakwah, dengan menghindari lawan arus terhadap orang yang belum mengapresiasi Islam. ${ }^{12}$

Dikemukakan oleh salah seorang tokoh PKS nasional, bahwa apa yang menjadi kajian pada halaqah tarbiyah sesungguhnya materi keislaman yang sama-sama menjadi kajian dan keyakinan seluruh umat Islam. Artinya dari segi materi tidak ada perbedaan. Namun yang menjadi berbeda dan menjadi sejarah ketika pola pendekatan kajianya dibuat integral

\footnotetext{
${ }^{12} \mathrm{http}: / /$ kabarjakarta.com/blog/partai-keadilan sejahtera-gerakan-tarbiyah-indonesia
} 
dan menjadi aplikatif. Kalau di berbagai tempat ukhuwah masih menjadi teriakan-teriakan yang semu, di lingkungan Tarbiyah, itu diaplikasikan. Kalau penguasaan Islam selama ini masih bersifat kognitif, maka di Tarbiyah hal itu dicoba untuk diamalkan. Tema yang dikaji dalam beberapa kali pertemuan harus ditransformasikan dari dairatul qaul (perkataan, teori), kepada dairatul amal (pengamalan). Kemudian dari amal kepada kebiasaan. Kalau Islam dulu dibatasi pada bidang-bidang dan ruang-ruang tertentu, maka di Tarbiyah hal itu diperluas sebagaimana Islam adanya yang berbicara juga tentang politik, ekonomi dan lain-lain. Dengan kata lain ada orientasi kepada Islam kaffah (total). Mereka dibangun kesadarannya untuk melihat bahwa pemahaman Islam mereka sebelum ini harus diluruskan. Demikianlah sebuah upaya yang dilakukan Tarbiyah supaya Islam dapat diamalkan dalam satu komunitas baru.

Disamping itu, menurutnya, dengan proses kesejarahan itu, maka saat ini adalah era baru dimana dakwah yang selama ini sering diumbar di mimbar mendapatkan perluasan dan diversifikasinya yakni yang melanjut menjadi dakwah kader. Mereka inilah yang dalam konsep dakwah tarbiyah disebut dengan anasirut taghyir (elemen perubah). Dalam proses dakwah ada obyek yang hanya bisa sekedar menerima dakwah yakni qoobilud dakwah. Ada yang bisa menerima perubahan dari dakwah itu, yakni qoobilut taghyir ada yang berpotensi menjadi anasirut taghyir. Nah, anasirut taghyir ini, ada di kawasan ilmiah, yakni kampus-kampus dan sekolah-sekolah. ${ }^{13}$

Gerakan dakwah tarbiyah mulai memiliki pengaruh yang agak kuat di masyarakat sejak tahun 1990-an. Gerakan tarbiyah melakukan gerakan pada masyarakat dengan berbasiskan masjid-masjid, semula dari masjid kampus sebagaimana awal pendiriannya. Masjid Salman ITB dan Masjid Al Falah di IPB Bogor adalah cikal-bakal gerakan tarbiyah yang berlangsung di Indonesia.

Para aktivis dakwah kampus dapat dikatakan sebagai bibit-bibit yang selanjutnya menjadi perintis partai keadilan. Mereka bukan tokoh yang sudah dikenal luas, mereka hanyalah anak-anak muda biasa yang berkeinginan untuk mengamalkan ajaran-ajaran keagamaan yang mereka yakini sebagai ajaran agama

\footnotetext{
${ }^{13}$ Diambil dari tulisan pada seminar "Tarbiyah di Era baru"

http://syiar.wordpress.com/2007/10/27/ikhwanulmuslimin-inspirasi-gerakan-tarbiyah/
} 
yang universal dan menyeluruh dengan sedikit upaya untuk memperluas kesadaran keagamaan itu dalam berbagai aspek kehidupan termasuk politik. Terkait dengan partai politik, dalam kegiatan tarbiyah, diberikan materi saluran politik yang bertujuan agar peserta tarbiyah dapat mengetahui hak-hak sosialnya dalam dunia politik, membandingkan beberapa saluran politik untuk melihat kelebihan, kesamaan, dan kekurangannya dengan objektif, memilih saluran politik dengan benar yang sesuai dengan aspirasinya, dan terlibat aktif untuk menyalurkan ideidenya dalam memperbaiki masyarakat pada saluran politik yang dipilinnya. ${ }^{14}$

Generasi muda yang giat berdakwah tersebut mendirikan dan mengelola pengajian yang diwadahi dalam bentuk lembaga dakwah kampus (LDK). Lembaga ini kerap menyelenggarakan berbagai aktivitas keagamaan, seperti pengajian untuk mahasiswa. Aktivitas keagamaan lembaga tersebut, lebih bersifat rahasia atau lebih sering dilakukan secara diam-diam dan jika lembaga tersebut menyelenggarakan pengajian untuk banyak orang, mereka berkamuflase

${ }^{14}$ (Tim Kaderisasi DPP PKS, 2003). mengatasnamakan

kegiatan mahasiswa. Hal ini sengaja mereka lakukan karena pada masa itu, rezim yang berkuasa adalah rezim Soeharto. Rezim ini dikenal sangat represif terhadap gerakan keagamaan. Akan tetapi, situasi tersebut mulai berubah pada era 1990-an, saat Soeharto mulai menempatkan para aktivis Islam sebagai sekutu. Sejak saat itulah, gerakan yang semula bernama Usroh ini berganti nama menjadi Ikhwan dan mereka menamai aktivitas mereka dengan sebutan Tarbiyah. ${ }^{15}$

Sekitar awal tahun 1998, tepatnya 20 Juli 1998, kader-kader gerakan tarbiyah mendirikan partai politik Islam yaitu Partai Keadilan (PK) yang kemudian berganti nama menjadi Partai Keadilan Sejahtera (PKS) di tahun 2001. Meski telah bertransformasi menjadi partai politik, metode pembinaan yang digunakan PKS tetap mengacu pada sistem pengkaderan dakwah tarbiyah. Ciri khas gerakan tarbiyah ini adalah membentuk halaqah-halaqah (kelompok-kelompok) kecil yang terdiri dari lima hingga dua belas orang anggota (mutarabbi) dibimbing oleh seorang murabbi bahkan dalam realisasinya satu atau dua orang

\footnotetext{
${ }^{15} \mathrm{http}: / /$ kabarjakarta.com/blog/partai-keadilansejahtera-gerakan-tarbiyah-indonesia
} 
anggota pun jadi untuk dikader dan dibina sehingga memiliki wawasan keislaman yang kuat. Contoh lainnya dari proses kaderisasi dan regenerasi dalam tubuh PKS yaitu dengan melaksanakan pelatihan-pelatihan dan kegiatan-kegiatan/daurah.

Dari

berbagai jenis daurah tarbiyah (sarana untuk membekali peserta tarbiyah dengan pengalaman untuk pengembangan keahlian dan pengetahuan), terdapat daurah yang merupakan kegiatan sosial-politik misalnya daurah penyelenggaraan/ pengawasan pemilu dan pengelolaan lembaga kemasyarakatan (RT, RW, Badan Desa, LSM). ${ }^{16}$

\section{Program Kegiatan halaqah tarbiyah} PKS

Halaqah Tarbiyah PKS memiliki kegiatan yang disusun secara terprogram. Program kegiatan tersebut bukan sekedar dalam rangka transfer ilmu dari seorang Murabbi kepada anggotanya, melainkan lebih kepada upaya perubahan prilaku keagamaan anggota yang dilakukan melalui pencerahan dan proses pembiasaan yang dievaluasi secara terus-menerus. Selain itu ada juga program kegiatan yang memiliki muatan kepartaian sekalipun hanya sedikit yaitu melalui mengikut sertakan para anggotanya dalam kegiatan partai. Program halaqah tarbiyah meliputi 10 Pokok Program:

1. Salimul 'Akidah : 'Akidah yang benar

2. Shohihul Ibadah: Ibadah yang benar

3. Matinul khuluk : Akhlak yang mapan

4. Qadiru 'ala al-kasbi: Kemampuan berusaha/bekerja

5. Mutsaqaful fikri: bekal pemikiran/wawasan

6. Qawiyul Jismi : jasad yang kuat

7. Mujahidun Linafsi: kesungguhan diri

8. Munazzam fi Syu'nihi: Manajemen diri

9. Harishun 'Ala Waktihi : Manajemen waktu

10. Nafi'un Lighairihi:

Bermanfaat untuk orang lain

Dari sepuluh materi pokok tersebut, biasanya masing-masing halaqah menyusun program kegiatan per satu tahun atau per enam bulan yang sudah disepakati antara murabbi dengan anggotanya pada awal pertemuan.

\footnotetext{
${ }^{16}$ (Tim Kaderisasi DPP PKS, 2004).
} 
3. Materi dakwah pada Halaqah Tarbiyah PKS

Ketika penulis menanyakan tentang materi dakwah halaqah tarbiyah, jawaban responden hampir sama, bahwa materi yang disampaikan adalah materi ke-Islaman yang terfokus pada sepuluh program sasaran utama atau tujuan halaqah tarbiyah, seperti tersebut di atas. Untuk lebih mengetahui seluruh kandungan materinya, seorang murabbi (istilah bagi Pembina halaqah tarbiyah PKS) menunjukan kepada peneliti beberapa buku panduan yang berisi kumpulan materi ke-Islaman. Buku tersebut diantaranya "Modul tarbiyah Islamiyah jilid 1 \& 2, dan buku Kepribadian Muslim Bahan panduan bagi da'i dan Murabbi.

Setelah dikaji, modul dan buku panduan tersebut memang memuat materi ke_islaman yang terkandung dalam Al-Qur'an. Materi- materi tersebut nampaknya sudah disusun secara sistematis dan terstruktur dengan mengacu pada 10 sasaran utama halaqah. Sistematika penulisan buku atau modul tersebut ditulis secara rinci, tidak hanya kandungan materi yang ditulis secara lengkap, tetapi tujuan dan metode pembelajaran dari masing-masing materi pun sudah disusun secara terperinci. Hal ini tiada lain untuk memudahkan para murabbi (Pembina) dan adanya keseragaman dan kesamaan materi dalam mencetak pribadi muslim yang kamil

\section{E. Keunikan pada Halaqah Tarbiyah PKS}

\section{a. Stelsel Halaqah/ MLM}

Setelah melakukan wawancara dengan beberapa kader yang sekaligus juga murabbi dan ada juga peserta halaqah, serta observasi di lapangan, memang tidak dapat dipungkiri bahwa halaqah tarbiyah dapat dikatakan sebagai sarana rekrutmen dan kaderisasi. Seperti diakui oleh seorang peserta halaqah yang sudah sejak di bangku SMU hingga di kampusnya ia mengikuti kegiatan halaqah. la menuturkan bahwa ketika pertama kali masuk di kegiatan halaqah yang ada di sekolahnya, ia mengaku tidak tahu kalau itu kegiatan salah satu partai, karena waktu itu diajak temanya. Tetapi setelah beberapa kali diikuti dan kajianya tentang ke-Islaman akhirnya ia merasa nyaman mengikuti kegiatan halaqah tersebut sampai berlanjut di kampus ketika itu katanya di salah satu Universitas di Yogyakarta. la mengaku saat pindah dari Pontianak ke Yogya tidak ada kesulitan untuk 
mengikuti halaqah, karena sudah dikoordinasikan langsung oleh murabinya. Begitu juga setelah selesai kuliah dan kembali ke Pontianak, seperti sekarang ia tergabung kembali di halaqah yang ada di wilayahnya ia tinggal.

Dalam upaya rekrutmen kader, PKS memiliki langkah-langkah yang jelas. Seperti fenomena di atas, bahwa untuk mengajak dan mengenalkan Islam sekaligus partai kepada objek dakwah dapat dilakukan melalui pendekatan personal, diantaranya pendekatan dengan teman. Maksudnya, mereka yang sudah tergabung menjadi peserta halaqah dianjurkan untuk mengajak atau merekrut temannya dan bergabung menjadi peserta halaqah. Upaya rekrutmen PKS ini, sebenarnya mengacu pada strategi dakwah yang dilakukan oleh Rasulullah saw. Ketika beliau menyampaikan islam kepada Abu Bakar Ass-Shiddiq Ra, ternyata melalui seruan Abu Bakar banyak orang Quraisy yang menyatakan keislamanya kepada Nabi. Mereka yang masuk islam melalui Abu Bakar adalah Utsman bin Affan, Zubair bin Awwam, Thalhah bin Ubaidillah, Sa'ad bin Abi Waqosh, Abdurrahman bin Auf, Abi
Ubaidah bin Al-jarrah dan Arqom bin Abi Arqom.. ${ }^{17}$

\section{b. Membentuk kader da'i handal}

Sebagaimana dijelaskan di muka bahwa "halaqah' merupakan sarana tarbiyah untuk mencapai tujuan tarbiyah yang sudah diprogramkan dalam kurikulum tarbiyah. Akan tetapi dalam halaqah tarbiyah ini, peneliti menemukan bukan sekedar penyampaian materi yang diberikan oleh seorang murabbi kepada mutarobbi. Namun terlihat adanya upaya "mencetak seorang da'i atau murabbi". Hal ini dilihat dari adanya beberapa metode dakwah yang diterapkan selama halaqah, yang dirasakan mengarah pada kaderisasi da'i. Metode tersebut diantaranya, Metode Ceramah dan Tanya jawab, Metode Penugasan dan Pembiasaan, Bedah buku (oleh peserta), Menjalankan Amalan yaumi (amalan sunnah harian), Metode Tatsqif (menambah wawasan), dan Metode Muhasabah.

Tidak hanya tsaqafah fikriyah yang harus dimiliki seorang murabbi, akan tetapi kesucian jiwa atau hati sangat penting untuk dimiliki. Dalam upaya pengecasan ruhani ini biasanya

\footnotetext{
${ }^{17}$ Husain MuhammadYusuf, Jejak Dakwah Rasulullah ( Bandung: Pustaka Kasidah Cinta, 2002) hal 22-23
} 
dalam waktu tiga bulan sekali seluruh halaqah yang berada dalam satu wilayah, atau ranting diundang oleh pengurus bidang kaderisasi partai untuk mengikuti kegiatan bersama yang dipusatkan di satu tempat biasanya di Masjid. Ada dua istilah yang digunakan dalam muhasabah ini, yaitu mabit dan jaltsah ruhiyah.

Mabit yang secara bahasa berarti menginap, merupakan kegiatan muhasabah atau latihan ruhani yang biasa dilakukan oleh halaqah laki-laki atau ikhwan. Kegiatan mabit ini biasa dilakukan antara tiga bulan sekali dan merupakan program kaderisasi patai. Seperti kegiatan tasqif, seluruh halaqah yang terhimpun dalam satu ranting atau DPC bergabung di satu masjid terdekat untuk melakukan kegiatan bersama.

Dimulai dari pukul 20.00 hingga pukul 22.00 malam peserta mabit disuguhi dengan kajian materi Keislaman. Setelah itu peserta beristirahat hingga pukul 02 atau 03 . Dari pukul 02 peserta dibangunkan untuk menjalankan shalat tahajud bersama, dan tilawah hingga waktu shalat subuh tiba.

Setelah menjalankan shalat subuh berjama'ah, dilanjutkan dengan kuliah subuh, pembacaan al-ma'tsurat dan muhasabah hingga pukul 06 pagi.
Untuk mengakhiri kegiatan mabit ini, peserta halaqah melakukan kegiatan olah raga yang dalam istilah halaqah dikenal dengan kegiatan "riyadhah". Biasanya mereka melakukan senam atau olahraga putsal.

Sebagaimana mabit yang dilakukan halaqah ikhwan, halaqah akhwat atau perempuan juga melakukan kegiatan yang sama yang dikenal dengan istilah jaltsah ruhiyah. Yang membedakanya kalau mabit kegiatanya menjelang malam hingga pagi dan pesertanya bermalam di masjid, kalau dalam kegiatan jaltsah ruhiyah peserta tidak menginap. Kegiatannya biasa dilakukan dari jam 14 hingga pukul 17 sore atau jika tepat di bulan Ramadhan atau biasanya pada waktu shaum sunnah Senin atau Kamis, maka kegiatan berakhir dengan ifthor/buka bersama.Kegiatan yang dilakukan sekitar 3 jam itu diisi dengan beberapa amalan, yaitu: penyampaian materi tentang manajemen hati, memperbaiki diri, shalat berjama'ah, al-ma'tsurat, do'a khusyu' dan muhasabah.

\section{F. Penutup}

Merujuk pada teori ilmu dakwah, halaqah tarbiyah Partai Keadilan Sejahtera yang lebih dikenal dengan 
halaqah tarbiyah, merupakan bentuk dakwah fiah qolilah. Terdiri dari kelompok kecil yang berjumlah antara 5-10 orang, dibina secara intensif dengan materi taklim yang sangat variatif. Sekalipun di dalamnya ada upaya kaderisasi partai, namun pada prakteknya halaqah tarbiyah ini dapat dikatakan benar-benar membina ummat menuju masyarakat yang islami. Tidak hanya membekali anggotanya dengan materi keislaman untuk menuju muslim yang kaffah, akan tetapi dalam halaqah ini berupaya membentuk seorang da'l atau murabbi yang memiliki kecerdasan akal, ruhani, emosional, sehat jasmani serta terampil dan berakhlak mulia. Dalam upaya mewujudkanya, para murabbinya dibekali dengan materi-materi ke-Islaman yang lengkap yang telah disusun secara terstruktur dan sistematis yang diterapkan dalam berbagai metode dakwah. Dengan demikian setelah dikaji, terdapat beberapa keunikan pada halaqah tarbiyah, yaitu (1) stelsel halaqah, (2) metode pembentukan kader da'i handal.

\section{G. Daftar Pustaka}

Abdullah Qadiri, 1993, Adab Halaqah, Bandung: PT. Al-Ma'arif.

Aep Kusnawan 2004. IImu Dakwah Kajian Berbagai Aspek. Bandung: Pustaka Bani Quraisyi
Ahmad Bin Muhammad Al-Dasimi Al'Adnany, 2008, Al-Da'wah AlIslamiyah $\mathrm{Li}$ al-Ifrad wasyabab, Madinah Munawwarah: Daar AlZaman.

Ahmad warson Munawwir, 1997, AlMunawwir Kamus Arab-Indonesia, Surabaya: Pustaka Progresif.

Al-Bayanuni, Muhammad Abdul fatah. 2001. Al-Madkhall ila 'ilmi alDakwah. Beirut: Resalah Publishers.

Ali Mustafa Yaqub, 2000, Sejarah dan Metode Dakwah Nabi, Jakarta: Pustaka Firdaus

Asep Muhyiddin, 2002, Metode Pengembangan Dakwah. Bandung : Pustaka Setia.

Bukhari, Shahih Bukhari, bab anbiya

Cucu Nurjamilah, 2010, Dakwah Muslimah Center Daarut Tauhid Bandung sebagai Model Dakwah terhadap Perempuan Perkotaan, "Tesis Pasca Sarjana Pendidikan Agama Islam

Effendy, Onong Uchjana. 1993. IImu, Teori dan Filsafat Komunikasi. Bandung: PT. Citra Aditya Bakti Enjang \& Aliyuddin. 2009. Dasar-dasar IImu Dakwah. Bandung: Widya Padjajaran.

Harjani Hefni, dkk, 2003, Metode Dakwah, Jakarta: Prenada Media. 
http://kabarjakarta.com/blog/partai-

keadilan-sejahtera-gerakan-

tarbiyah-indonesia

http://syiar.wordpress.com/2007/10/27/ikh

wanul-muslimin-nspirasi-gerakantarbiyah/(Tim Kaderisasi DPP PKS, 2003).

Jalaluddin Rahmat, 1999, Rekayasa

Sosial: Reformasi atau Revolusi, Bandung: PT Remaja Rosda Karya.

Koentjaraningrat dan Emerson Donald K. 1993. Aspek Manusia dalam Penelitian. Jakarta: PT. Gramedia Krech, david, Crutchfield dan Richard, S. 1982. Individul In Society. Berkeley: University Of California Press

M. Arifin, 1991, IImu pendidikan Islam, Jakarta: Bumi Aksara.

Muslim, Shahih Muslim, jilid 5, no.142

Samsul Nisar, 2007, Sejarah Pendidikan Islam (menelusuri jejak Sejarah Pendidikan Era Rasulullah Sampai indonesia), jakarta; Kencana.

Sarlito Wirawan Sarwono.2005. Psikologi Sosial Psikologi Kelompok dan Terapan. Jakarta: balai Pustaka

Sugiyono.2008. Metode Penelitian Kuantitatif, Kualitatif dan $R$ \& $D$. Bandung: Alfabeta,

Syukriadi Sambas, 2008. Teori Dakwah Fi'ah, Makalah Kuliah IImu Dakwah PPS UIN SGD Bandung
2008

Materi

Perkuliahan Teori IImu Dakwah I, Wahyu Ilaihi dan Harjani Hefni, 2007, Pengantar Sejarah Dakwah, Jakarta: kencana 